\title{
CAWA LAMPUNG : KAMUS BAHASA INDONESIA- LAMPUNG DIALEK A BERBASIS ANDROID
}

\author{
Febi Eka Febriansyah ${ }^{1}$, Ardiansyah ${ }^{2}$, Afan Darmajii ${ }^{3}$ \\ Jurusan Ilmu Komputer FMIPA Universitas Lampung \\ 1febi_ef@yahoo.com, 2ardiansyah@fmipa.unila.ac.id, 3afandarmaji1551@gmail.com
}

\begin{abstract}
Indonesia is country rich in cultural diversity, one of which is regional languages. In the Law of the Republic of Indonesia Number 24 of 2009 article 1 paragraph 6, what is meant by regional languages is the language used for generations by Indonesian citizens in regional areas in the territory of the Unitary State of the Republic of Indonesia. There are many regional languages in Indonesia, one of which is Lampung. however, the reduction in Lampung language speakers can cause the Lampung language to disappear. With the help of technology, especially Android, it can help to increase interest in Lampung language, especially in Lampung adolescents. this research will develop an Indonesian translator application to the Lampung dialect $A$ on the Android Platform. The application is named Cawa Lampung. the translation process is carried out by the system with word translation. Every word is carried out the stemming process using the Nazief Adriani stemming method. The system development method used is eXtreme Programming. From the functional test results, all functions went well, and from the nonfunctional results it has a value of $85.57 \%$ which means "very good".
\end{abstract}

Keywords: Android, Translate, Lampung language, Stemming Nazief Adriani Algorithm

\begin{abstract}
Abstrak
Indonesia adalah negara yang kaya akan keragaman budaya, salah satunya adalah bahasa daerah. Dalam Undang-Undang Republik Indonesia Nomor 24 tahun 2009 pasal 1 ayat ke 6, yang dimaksud bahasa daerah adalah bahasa yang digunakan secara turuntemurun oleh warga negara Indonesia di daerah daerah di wilayah Negara Kesatuan Republik Indonesia. Ada banyak bahasa daerah di Indonesia, salah satunya adalah bahasa lampung. namun berkurangnya penutur bahasa lampung dapat mengakibatkan bahasa daerah lampung akan hilang. Dengan bantuan teknologi terutama Android, dapat membantu meningkatkan lagi minat berbahasa lampung terutama pada remaja lampung. penelitian ini akan mengembangkan aplikasi translator bahasa Indonesia ke Bahasa Lampung dialek A pada Platform Android. Aplikasi diberi nama Cawa Lampung. proses terjemahan dilakukan oleh sistem dengan terjemahan kata perkata. Setiap kata dilakukan proses stemming dengan mengunakan metode stemming Nazief Adriani. Metode pengembangan sistem yang digunakan yaitu eXtreme Programming. Dari hasil pengujian fungsional semua fungsi berjalan dengan baik, dan dari hasil non fungsional memiliki nilai $85.57 \%$ yang memiliki makna "sangat baik"..
\end{abstract}

Kata kunci: Android, Terjemahan, Bahasa Lampung, Algoritma Stemming Nazief Adriani

Cawa Lampung : Kamus Bahasa Indonesia-Lampung Dialek A Berbasis Android (Febi E.F)| $\mathbf{3 3 1}$ 


\section{PENDAHULUAN}

Indonesia adalah negara yang kaya akan keragaman budaya, salah satunya adalah bahasa daerah. Dalam Undang-Undang Republik Indonesia Nomor 24 tahun 2009 pasal 1 ayat ke 6, yang dimaksud bahasa daerah adalah bahasa yang digunakan secara turun-temurun oleh warga negara Indonesia di daerah daerah di wilayah Negara Kesatuan Republik Indonesia. Bahasa daerah juga merupakan Bahasa yang unik karena memiliki ciri tersendiri di masing-masing Bahasanya. Sedangkan dalam statistik kebahasaan tahun 2019, jumlah bahasa daerah yang terverifikasi dan termutakhir menurut dialektolog ada 668 bahasa daerah yang tersebar di seluruh penjuru Indonesia [1].

Lampung merupakan salah satu Provinsi yang letaknya sangat strategis. Terletak di paling selatan pulau Sumatra membuat Provinsi Lampung merupakan tujuan pertama ketika ingin masuk ke Pulau Sumatra melalui jalur laut [2]. Mudahnya akses masuk ke Provinsi Lampung membuat masyarakat di Provinsi Lampung semakin beragam. Beragamnya masyarakat yang ada di Lampung, berdampak pada masyarakat Lampung. Dampak dari beragamnya suku yang ada di Lampung adalah memudarnya budaya asli dari Lampung, salah satunya adalah Bahasa.

Untuk mencegah kematian bahasa daerah, perkembangan teknologi yang dapat dimanfaatkan, salah satunya adalah smartphone Android. Katadata.co.id dalam web databoks.katadata.co.id tahun 2017 mengungkapkan bahwa Sistem Operasi (SO) Android saat ini telah mendominasi perangkat mobile (bergerak) di seluruh penjuru dunia. Laporan yang bertajuk Global Stashot: Digital in Q3 2017, menunjukkan bahwa sebanyak $72,9 \%$ pengguna piranti bergerak global menggunakan SO Android. Selain itu Asosiasi Penyelenggara Jasa Internet Indonesia (APJII) mengungkapkan bahwa pada tahun 2017, dari total 143,26 juta jiwa pengguna aktif internet di Indonesia, 50,08\% memiliki smartphone/tablet [3].

Dalam penelitian ini akan dikembangkan sebuah aplikasi yang dapat digunakan untuk mempermudah terjemahan bahasa. Aplikasi ini dihararapkan mampu meningkatkan lagi minat masyarakat terhadap bahasa lampung.

Adapun batasan masalah pada penelitian ini adalah:

1. Aplikasi berbasis Android.

2. Bahasa tujuan dari terjemahan adalah Bahasa Lampung dialek A.

3. Aplikasi tidak membutuhkan koneksi internet.

4. Masukan / inputan teks dalam aplikasi ini adalah teks dalam Bahasa Indonesia baku.

Adapun tujuan dari penelitian ini adalah:

Tujuan dari penelitian ini adalah mengembangkan aplikasi terjemahan Indonesia Lampung dialek A berbasis Android.

Adapun manfaat yang didapat dari penelitian ini adalah:

1. Membantu dalam pencarian terjemahan Bahasa Indonesia ke Bahasa Lampung.

2. Aplikasi ini merupakan salah satu upaya dalam melestarikan Bahasa Lampung. 
3. Aplikasi ini diharapkan dapat memudahkan pengguna dalam berkomunikasi dengan Bahasa Lampung dan meningkatkan minat pengguna dalam mempelajari Bahasa Lampung.

\section{METODOLOGI PENELITIAN}

Metode yang digunakan pada penelitian ini meliputi beberapa tahapan. Tahapan yang dilakukan yaitu studi literatur, pengumpulan data, perancangan sistem yang meliputi desain interface dan desain UML, coding atau implementasi dan testing. Untuk mengimplementasikan aplikasi penerjemah Bahasa Indonesia ke Bahasa Lampung pada Platform Android, digunakan metode pengembangan sistem eXtreme Programming.

\subsection{Studi Literatur}

Studi literatur dilakukan dengan mempelajari tentang afiks verba Bahasa Lampung. Selain itu dilakukan juga studi tentang penggunaan stemming dengan menggunakan algoritma Nazief dan Adriani untuk melakukan stemming Bahasa Indonesia. Studi literatur ini dilakukan dengan mempelajari melalui media internet, buku-buku, dan jurnal penelitian terkait.

\subsection{Pengumpulan data}

Pengumpulan data pada penelitian ini dilakukan melalui studi pustaka. Data yang digunakan adalah kosakata Bahasa Lampung dialek A. Perbedaan yang dari kedua dialek itu terdapat pada fonemnya. Untuk dialek abung kata-katanya diakhiri dengan fonem /o/. sedangkan untuk dialek pesisir, kata-katanya diakhiri dengan fonem /a/ [4]. Selain kosakata dialek A, data yang digunakan juga berupa afiks verba Bahasa Lampung. Data diperoleh dari buku Kamus Dwi Bahasa Indonesia-Lampung Dialek Way Kanan dan buku afiks verba Bahasa Lampung yang ditulis oleh Aryani (2016). Afiks adalah bentuk terikat yang bila ditambahkan pada bentuk lain akan mengubah makna gramatiknya [5]. buku afiksasi verba bahasa lampung menjelaskan bahwa afiks adalah bentuk yang muncul sebelum stem atau sesudah stem [6].

\subsection{Perancangan Sistem}

Perancangan sistem merupakan tahapan rencana pengembangan sistem ke dalam bentuk desain yang digunakan untuk memudahkan pengguna melihat rancangan sistem yang dibuat. Perancangan Aplikasi kamus Indonesia-Lampung terdiri atas perancangan usecase diagram, activity diagram dan desain antarmuka (interfaces) aplikasi. metode pengembangan sistem yang digunakan dalam penelitian ini adalah metode eXtreme Programming.

\subsection{Pengujian}

Pengujian aplikasi dilakukan setelah proses pengkodean (coding) selesai. Pegujian aplikasi menggunakan metode pengujian black box. Pengujian black box adalah pengujian untuk menguji fungsional dari sebuah sistem. Selain itu 
dilakukan pengujian untuk menilai seberapa baik aplikasi dengan menggunakan user acceptance test.

Menjelaskan kronologis penelitian termasuk cara menyiapkan bahan penelitian, rancangan atau desain penelitian, prosedur penelitian (dalam bentuk algoritma, pseudocode atau lainnya), cara pengujian dan pengambilan data. Pada bagian ini boleh juga diberikan dasar teori. Tabel dan Gambar dibuat center seperti di bawah ini dan diacu pada naskah.

\section{HASIL DAN PEMBAHASAN}

\subsection{Analisa Kebutuhan Data}

Data yang dibutuhkan adalah data berupa kosakata Bahasa Indonesia beserta terjemahannya dalam Bahasa Lampung dialek A, dan data afiksasi verba Bahasa Lampung. Kosakata yang yang ada dalam kamus ada sebanyak 4.138 kata, dan 9 afiksasi verba dalam Bahasa Lampung. Data diperoleh dari buku kamus dwi bahasa dialek way kanan dan buku afikasasi verba bahasa lampung.

Data kosakata dari kamus digunakan untuk membuat database yang berisi kosakata Bahasa Indonesia dan kosakata Bahasa Lampung. Data afiksasi verba Bahasa Lampung digunakan sebagai aturan untuk menentukan prefiks dan suffiks untuk hasil terjemahan. Data kamus digunakan untuk proses terjemahan Bahasa Indonesia ke Bahasa Lampung.

\subsection{Analisa kebutuhan sistem}

Kebutuhan perangkat yang dibutuhkan untuk menjalankan aplikasi terjemahan Bahasa Indonesia ke Bahasa Lampung dialek A pada Platform Android ditampilkan pada Tabel 1.

Tabel 1. Analisa Kebutuhan sistem

\begin{tabular}{lll}
\hline No & Nama komponen & \multicolumn{1}{c}{ Spesifikasi } \\
\hline 1 & Sistem operasi & Android 5.0 (lollipop) \\
2 & RAM & $1 \mathrm{~GB}$ \\
3 & Internal & $8 \mathrm{~GB}$ \\
4 & Display & 4,5 inch \\
\hline
\end{tabular}

\subsection{Implementasi}

Pada penelitian ini, aplikasi dibangun dalam platform Android dengan menggunakan bahasa pemrograman Java dan database SQLite. Aplikasi ini bertujuan untuk melakukan terjemahan Bahasa Indonesia ke Bahasa Lampung atau sebaliknya. Pengembangan aplikasi ini dimulai dengan pengumpulan data kosakata kamus dan membuat database dari kamus. Data kamus diperoleh dari situs http://repository.lppm.unila.ac.id/820/ karya ibu Farida Aryani, M.Pd. Selain data kamus, untuk lebih mendapatkan informasi mengenai penelitian, dilakukan juga studi literatur. 
Pencarian terjemahan dalam aplikasi dilakukan dengan mencari kata per kata yang ada di dalam kamus. Ketika terdapat kata dengan imbuhan, maka kata tersebut akan di-stemming untuk dicari kata dasarnya. Proses stemming menggunakan algoritma Nazief dan Adriani. Setelah dilakukan proses stemming, dilakukan proses untuk pencarian imbuhan dalam kalimat terjemahannya. Penelitian ini telah melewati beberapa tahap, tahap perencanaan sistem, tahap analisis kebutuhan sistem, tahap desain sistem, untuk selanjutnya yaitu implementasi sistem.

Proses implementasi dilakukan dengan menggunakan IDE Android Studio 3.3 dan pengolahan database SQLite Studio. Aplikasi penerjemah Bahasa Indonesia ke Bahasa Lampung dialek A ini diberi nama Cawa Lampung. Tampilan dari aplikasi dapat dilihat pada Gambar 3 sampai dengan Gambar 7.

\subsubsection{Halaman splash screen}

Splash Screen merupakan tampilan awal setelah membuka aplikasi. Tampilan ini akan tampil ketika pengguna membuka ikon aplikasi dan tampil sebelum menu utama aplikasi terbuka. Tampilan splash screen menunjukkan logo aplikasi Cawa Lampung. Tampilan splash screen aplikasi Cawa Lampung ini dapat dilihat pada Gambar 3.

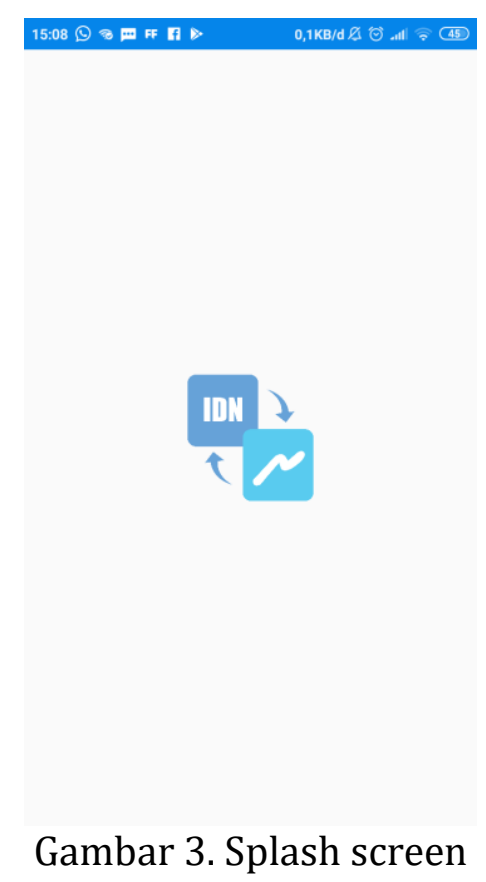

3.3.2 Halaman utama

Halaman utama merupakan halaman yang akan tampil saat pengguna mengakses aplikasi. terdapat 3 menu dalam halaman utama, yaitu halaman terjemahan, halaman bantuan, dan halaman tentang aplikasi. Halaman utama aplikasi ditampilkan pada Gambar 4 


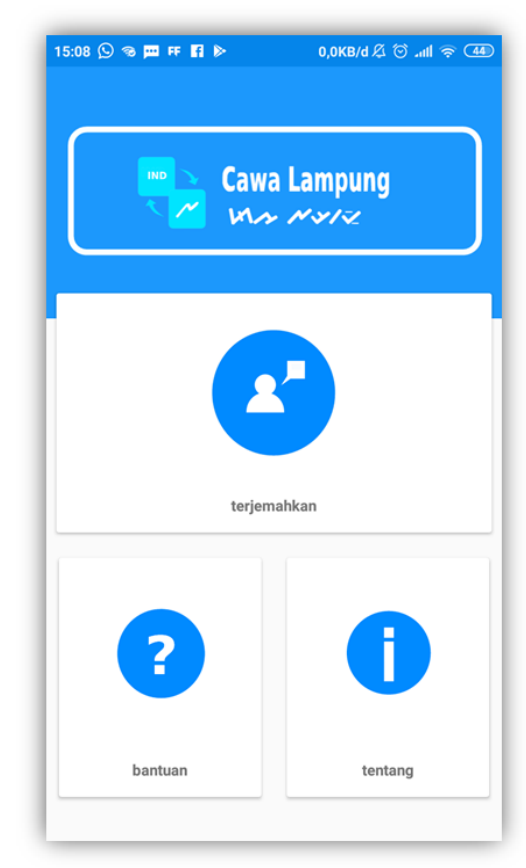

Gambar 4. Halaman utama

\subsubsection{Halaman terjemahan}

Halaman terjemahan merupakan halaman untuk melakukan terjemahan Bahasa Indonesia ke Bahasa Lampung, maupun sebaliknya. Proses terjemahan dapat dilakukan dengan menekan tombol terjemahan. Selain itu, untuk menghapus teks yang dimasukkan dapat dilakukan dengan menekan tombol delete. Tampilan halaman terjemahan dapat dilihat pada Gambar 5

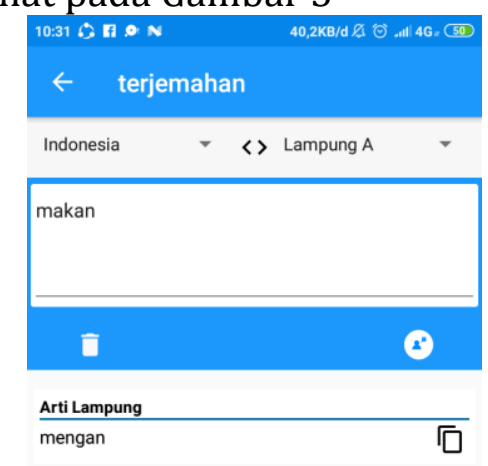

Gambar 5. Halaman terjemahan 


\subsubsection{Halaman bantuan}

Halaman bantuan merupakan halaman yang berisi petunjuk tombol dan menu dalam aplikasi. Halaman bantuan bertujuan untuk membantu pengguna dalam menggunakan aplikasi. Tampilan halaman bantuan ditampilkan dalam Gambar 6.

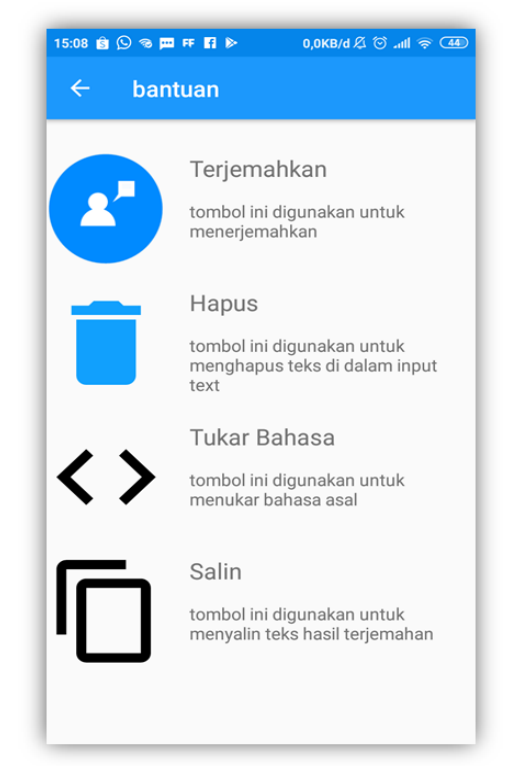

Gambar 6. Halaman bantuan

\subsubsection{Halaman tentang}

Halaman tentang merupakan halaman yang berisi informasi tentang aplikasi yang dikembangkan. Informasi yang disajikan dalam halaman ini adalah logo aplikasi, penjelasan tentang aplikasi, serta pengembang aplikasi. Halaman tentang ditampilkan pada Gambar 7.

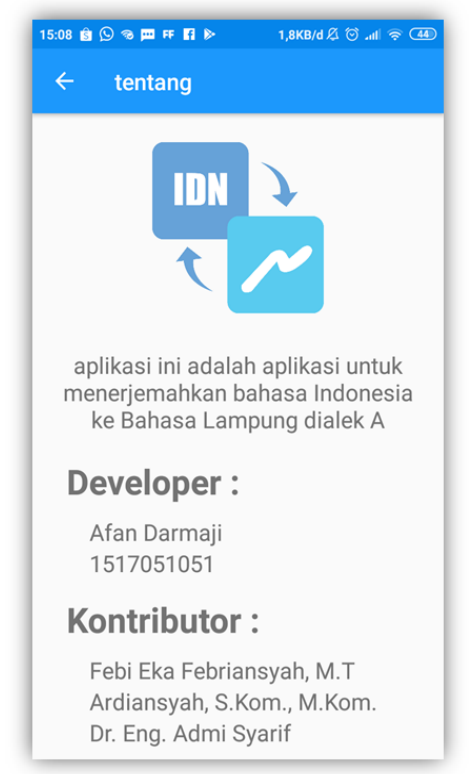

Gambar 7. Halaman tentang 


\subsection{Pengujian}

Dalam pengembangan sistem, pengujian merupakan hal yang harus dilakukan untuk memastikan sistem yang dikembangkan telah berjalan sesuai dengan requirement yang direncanakan. Pada pengembangan Aplikasi Penerjemah Bahasa Indonesia ke Bahasa Lampung dialek A pada Platform Android, pengujian dilakukan sebagai rujukan agar aplikasi dapat digunakan dengan baik. Dalam pengujian aplikasi, metode yang digunakan adalah metode Black Box Equivalence Partitioning (EP). Tabel pengujian fungsional dan non fungsional ditampilkan pada Tabel 2 dan Tabel 3.

Tabel 2. Pengujian fungsional

\begin{tabular}{|c|c|c|}
\hline Kelas Uji & $\begin{array}{l}\text { Skenario } \\
\text { Uji }\end{array}$ & $\begin{array}{l}\text { Hasil Yang } \\
\text { Diperoleh }\end{array}$ \\
\hline \multirow[t]{3}{*}{ User Interface } & $\begin{array}{l}\text { Memilih } \\
\text { menu } \\
\text { terjemahan }\end{array}$ & Berhasil \\
\hline & $\begin{array}{l}\text { Memilih } \\
\text { menu } \\
\text { bantuan }\end{array}$ & Berhasil \\
\hline & $\begin{array}{l}\text { Memilih } \\
\text { menu } \\
\text { tentang }\end{array}$ & Berhasil \\
\hline \multirow[t]{5}{*}{$\begin{array}{l}\text { Halaman } \\
\text { terjemahan }\end{array}$} & $\begin{array}{l}\text { Memilih icon } \\
\text { bahasa asal } \\
\text { terjemahan }\end{array}$ & berhasil \\
\hline & $\begin{array}{l}\text { Menekan } \\
\text { tombol } \\
\text { terjemahkan }\end{array}$ & berhasil \\
\hline & $\begin{array}{l}\text { Menekan } \\
\text { tombol } \\
\text { hapus } \\
\text { kata/kalimat }\end{array}$ & berhasil \\
\hline & $\begin{array}{l}\text { Menekan } \\
\text { tombol } \\
\text { tukar bahasa }\end{array}$ & berhasil \\
\hline & $\begin{array}{l}\text { Menekan } \\
\text { tombol salin } \\
\text { hasil } \\
\text { terjemahan }\end{array}$ & berhasil \\
\hline
\end{tabular}

Tabel 3. Pengujian non fungsional

\begin{tabular}{ccc}
\hline Pertanyaan & $\begin{array}{c}\text { Total } \\
\text { skor }\end{array}$ & Rata-rata (\%) \\
\hline 1 & 207 & 88.09
\end{tabular}




\begin{tabular}{ccc}
\hline Pertanyaan & $\begin{array}{c}\text { Total } \\
\text { skor }\end{array}$ & Rata-rata (\%) \\
\hline 2 & 200 & 85.11 \\
3 & 206 & 87.66 \\
4 & 207 & 88.09 \\
5 & 193 & 82.13 \\
6 & 190 & 80.85 \\
7 & 192 & 81.70 \\
8 & 209 & 88.94 \\
9 & 204 & 86.81 \\
10 & 203 & 86.38 \\
\multicolumn{2}{c}{ Rata rata }
\end{tabular}

Pengujian dilakukan oleh responden dengan jumlah 47 responden. Responden terdiri dari Mahasiswa, Pelajar, Guru, Administrator, Dosen, Wirausaha, dan Karyawan. Hasil jawaban dari kuesioner dianalisis dengan menggunakan perhitungan skala likert dengan interval tertentu. Berdasarkan Tabel 3. Dapat dilihat nilai rata rata menunjukkan angka $85.57 \%$ dengan hasil "sangat baik".

Tabel 4. Pengujian waktu terjemahan

\begin{tabular}{ccc}
\hline $\begin{array}{c}\text { Jumlah } \\
\text { Kata }\end{array}$ & $\begin{array}{c}\text { Jumlah } \\
\text { Karakter }\end{array}$ & $\begin{array}{c}\text { Rata rata } \\
\text { waktu per } \\
\text { artikel }\end{array}$ \\
\hline 20 & 144 & 1.02 \\
40 & 281 & 2.27 \\
60 & 411 & 4.20 \\
80 & 567 & 6.04 \\
100 & 709 & 10.93 \\
120 & 855 & 18.76 \\
140 & 993 & 29.65 \\
160 & 1140 & 48.89 \\
180 & 1275 & 51.25 \\
200 & 1421 & 71.73 \\
500 & 3309 & 1775 \\
1000 & 6455 & 6844 \\
1500 & 10269 & 9599 \\
\hline
\end{tabular}

Tabel 4 menunjukkan pengujian waktu yang dibutuhkan untuk melakukan terjemahan kata maupun kalimat. Waktu yang dibutuhkan untuk melakukan 
terjemahan akan semakin naik ketika jumlah karakter yang dimasukkan bertambah. Aplikasi ini dapat melakukan terjemahan hingga 1500 kata, namun memiliki waktu yang buruk yakni mencapai 9599 detik

\section{SIMPULAN}

Berdasarkan hasil penelitian dan implementasi, telah dibangun aplikasi penerjemah bahasa Indonesia ke bahasa Lampung dialek A pada platform Android yang diberi nama Cawa Lampung. Aplikasi ini dapat digunakan untuk melakukan penerjemahan kata atau kalimat dari bahasa Indonesia ke bahasa Lampung maupun sebaliknya. Pengembangan aplikasi "Cawa Lampung" memberikan kemudahan dalam melakukan terjemahan karena aplikasi dibangun dalam mode offline sehingga tidak membutuhkan jaringan internet dan dalam ukuran yang rendah. Berdasarkan hasil pengujian, fungsional dari aplikasi sudah berjalan sesuai dengan kebutuhan sistem. Namun untuk waktu terjemahan, aplikasi masih membutuhkan waktu yang lama untuk melakukan terjemahan diatas 150 kata. Berdasarkan hasil pengujian, hasil nilai pengujian pengguna menunjukkan hasil "baik".

Adapun saran dari penelitian ini adalah sebagai berikut.

a. Menambahkan dan melengkapi dialek A pada bahasa tujuan, sehingga aplikasi tidak hanya memiliki dialek A.

b. Menyempurnakan algoritma pencarian sehingga hasil yang diperoleh lebih baik dan waktu terjemahan menjadi lebih singkat.

c. Memperbaiki struktur kalimat dalam terjemahan sehingga kalimat hasil terjemahan dapat dibaca dengan baik dan benar..

\section{DAFTAR PUSTAKA}

[1] D. W. Hadi, W. Permanawiyat, N. Sambodo, A. O. Anindyatri, and Mas'ad, Statistik Kebahasaan 2019, 1st ed. Jakarta: Kementrian Pendidikan dan Kebudayaan, 2019.

[2] N. W. Putri, "Pergeseran Bahasa Daerah Lampung Pada Masyarakat Kota Bandar Lampung," J. Linguist., vol. 3, pp. 83-97, 2018.

[3] katadata.co.id, "73\% Perangkat Mobile Global Menggunakan Android | Databoks," $2019 . \quad$ [Online]. Available: https://databoks.katadata.co.id/datapublish/2017/10/09/73-perangkatmobile-global-menggunakan-android. [Accessed: 02-Apr-2019].

[4] Z. A. Aliana, S. Nursato, S. S. Arifin, S. Soetopo, and M. Waif, Ragam dan Dialek Bahasa Lampung. Jakarta: Pusat Pembinaan dan Pengembangan Bahasa, 1986.

[5] H. Kridalaksana, Pembentukan Kata dalam Bahasa Indonesia. Jakarta: PT. Gramedia Pustaka Utama, 2010.

[6] M. Aronof and K. Fudeman, What is Morphology. Malden Blackwell Publishing, 2005. 